Ann. Zootech., I968, 17 (4), 37I-374.

\title{
AN ASSESSMENT OF TWO METHODS OF DETERMINING THE AMOUNT OF RESIDUAL MILK
}

\author{
M. MORAG, 1 J. MARTINET,2 D. RAILLARD ${ }^{2}$ \\ ${ }^{1}$ Negev Institut: for Arid Zone Research, Beershera (Israel) \\ ${ }^{2}$ Laboratoire de Physiologie de la Lactation, \\ Centre national de Recherches zootechniques 78 -Jouy-en-Josas \\ Institut national de la Recherche agronomioue
}

\section{SOMMAIRE}

I. Chez la Brebis, le lait résiduel est extrait sous vide partiel, vers un système clos et stérile. Il est pesé, puis renvoyé dans la glande a fin de conserver celle-ci dans le même état de réplétion.

$\mathrm{Au}$ cours du retour du lait dans la glande mammaire, le $\mathrm{CO}_{2}$ contenu dans le lait est libéré et provoque un effet de "bouillonne nent ".

Cette technique entraîne un accroissement considérable (au moins I ooo fois) du nombre de leucocytes du lait et une décroissance de la production de zo à $30 \mathrm{p}$. roo.

2. Chez la Brebis et chez la Vache, le polyéthylène glycol (PEG) est utiliš comme marqueur pour estimer les quantités de lait résiduel.

T es quantités et concentrations variables de PEG sont introduites dans le canal du trayon.

Après des intervalles de temps allant de I à 24 heures, la distribution du PEG est déterminée dans les différentes fractions du lait contenu dans la glande.

La concentration du PEG dans ces différentes fractions est inconstante et sans aucun rapport avec les quantités de lait contenues dans la glande. Les pourcentages de récupération du PEG sont insatisfaisants ( 43 à $280 \mathrm{p}$. I00).

Alors que la technique du PEG - dilution est satisfaisante chez la Chèvre (KNutsson et Sper$B Z R, I 96 I$ ), les auteurs attribuent cet échec chez la Brebis et la Vache à une différence spécifique dans la morphologie mammaire.

An important criterium of milking efficiency is the volume of residual milk remaining in the mammary gland after milking. The usual method employed for measuring residual milk is to inject oxytocin following milking, and then to milk out the residual milk ejected by the exogenous hormone. 
This method, however, is unsuitable for milk secretion studies as both exogenous oxytocin and more thorough udder evacuation have been shewn to have a galactopoeitic effect.

This communication describes two techniques aimed at partially overcoming the disadvantages described above.

The work was carried out in the ewe and the cow.

\section{I. - MEASUREMENT OF RESIDUAL MILK AND RETURN OF THIS MILK TO THE MAMMARY GLAND}

An attempt was made to remove residual milk into a closed system, to weigh it and then to return it to the udder in the same physical, chemical and bacteriological state as it was in when removed.

After normal milking the teat was cleaned with alcohol and a sterile cannula inserted into the teat-canal. This cannula was connected to a sterile nylon blood-bag contained in a closed cylinder (See fig. I). Oxytocin was administered through a

UDDER

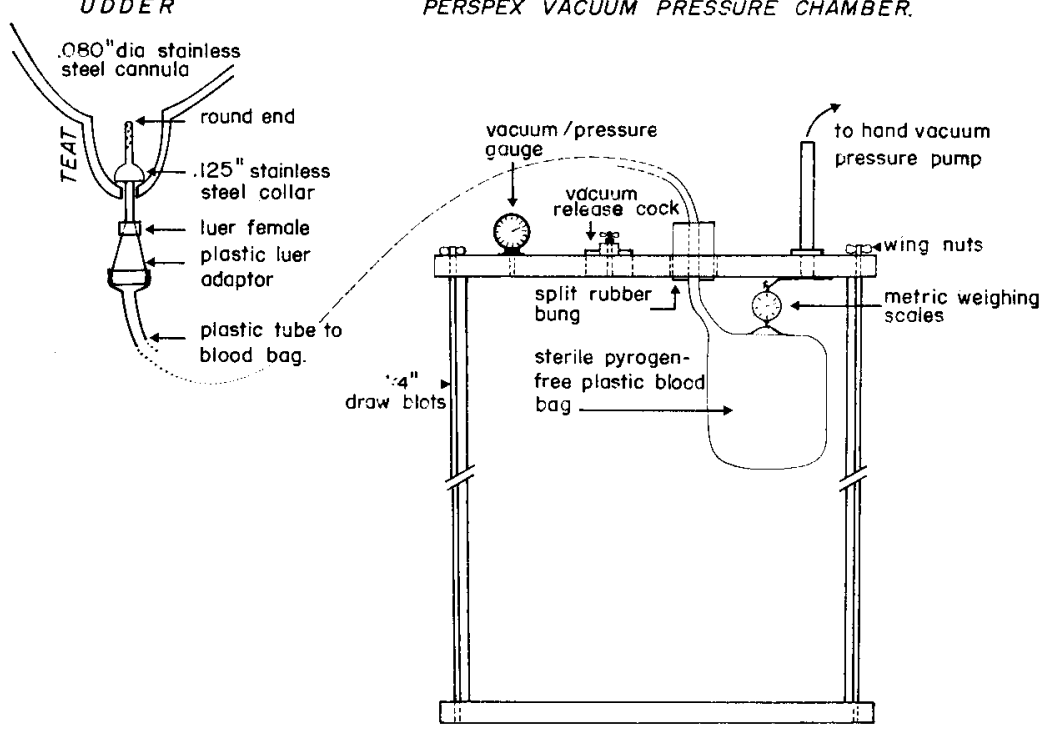

FIG. I. - Equipment used for the removal and return of residual milk Appareil pour extraire et réinjecter le lait résiduel

jugular cannula. Air was evacuated from the cylinder and at a vacuum level of $4 \mathrm{~cm} \mathrm{Hg}$, a satisfactory flow of residual milk into the blood bag was obtained. The milk was weighed in the bag. A small pressure of $6 \mathrm{~cm} \mathrm{Hg}$. was then built up around the bag, and the milk began to flow back into the udder. The return at the milk caused the ewe to react dramatically ; the animal jumped up and down on her hind legs. The experimenter put his hand on the udder to prevent the catheter from falling out and felt a distinct "bubbling " or "boiling " under the skin. This effect was 
produced every time milk was removed and returned via the closed system. IIt was suggested by DODD (personal communication), that the bubbling was caused by carbon dioxide which is normally dissolved in the milk, and which had been released by the conditions of the vacuum into the dead volume of the closed system; with the return of the milk the gas had been forced into the udder.

When a joint was inserted in the tube between the catheter and the bag, and was momentarily opened before the return of the milk, the bubbling effect was not produced. This last procedure entailed the return of residual milk, the composition of which differed from that of the milk previously removed.

The release of carbon dioxide could be avoided if during the removal and subsequent return of the milk, the volume of the closed system could be controlled, so that there was no dead space. This could possibly be done by using a large syringe directly connected to the catheter.

Several experiments of this type were carried out and the return of the residual milk was always shewn to have a deleterious effect on subsquent secretion. The yields fell 20 to $30 \mathrm{p}$. Ioo over the two days following the experiments. No clinical signs of mastitis were detected even after the bubbling effect, although the milk white cell count was always at least a thousand fold higher on the day following the treatment. In view of these undesirable effects, it was decided that the technique was not suitable for use in the experimental designs for the measurements of milk secretion rates in the ewe.

\section{2. - THE USE OF A MARKER IN THE EWE AND IN THE COW}

KnUtSSON and Sperber (I96I) described the use of polyethylene glycol (PEG) as a marker to estimate the different milk fractions in the gland of the goat. PEG introduced into the teat after milking was found to be uniformly distributed in the naturally ejected and residual fractions $I 6 \mathrm{~h}$ later. The authors noted that in short $4 \mathrm{~h}$ intervals the marker had not fully penetrated the residual fraction. They also reported a high recovery rate during late lactation.

In the present work several experiments were carried out in which ewes were milked $8, \mathrm{I} 2$ and $\mathrm{I} 6 \mathrm{~h}$ after the introduction of various concentrations of the marker (PEG) into both teats. The naturally ejected and residual fractions were each fractionated into several aliquots using milking equipment described elsewhere (MORAG, Gris and Fox, I967). It was found that the concentration of PEG in the various milk fractions was not constant and varied without any apparent pattern. Furthermore, recovery of the marker was unsatisfactory and ranged from 80 to I20 $\mathrm{p}$. I00.

Similar experiments were carried out in the cow. PEG was introduced into a single teat and the animals were milked after intervals of $\mathrm{I}-24 \mathrm{~h}$. As in the ewe, the concentrations of PEG varied greatly from fraction to fraction and again without any apparent pattern. Recovery was even less satisfactory and ranged from 43 to 280. p roo.

Previous in vitro tests had shown that PEG was uniformly distributed in bovine milk no matter what its composition, and that its recovery was satisfactory. In view 
of the consistently unsatisfactory nature of the results, the method was abandoned in both animals.

The apparent success of the marker technique in the goat (op. cit.) as opposed to its failure in the ewe and in the cow, may be due to differences of udder structure in these animals. The ratio of storage to secretory tissue is far greater in the goat than in the ewe and the cow. (TURNER, I95I). Similarly it seems that the flow between the alveoli and the cisterns may be freer in the goat. (ZAKs, I962).

\section{REFERENCES}

Knuttsson P. G., Sperber I., ig6r. Distribution and recovery of polyethelene glycol after injections into the udder of the goat. Lantbr Hosgk Annlr., 27, 33-40.

Morag M., GibB J. C., Fox S., 1967. A milking parlour for experimental work with lactating ewes. $J$. Dairy Res., 34, 21 5-220.

Turner C. W., I95I. In The mamary gland. Lucas Bros., Colombia, Mo.

Zaks M. G., I962. In The motor apparatus of the mammary gland. Oliver and Boyd. London. 